\title{
IMPACT OF ALKALIZATION OF SURPLUS ACTIVATED SLUDGE ON BIOGAS PRODUCTION
}

\author{
WPLYW ALKALIZACJI OSADU CZYNNEGO NADMIERNEGO \\ NA PRODUKCJE BIOGAZU
}

\begin{abstract}
Large amounts of sludge are produced in biological wastewater treatment plants. Since the sludge is highly contaminated, it has to undergo proper stabilization before it is disposed or utilized in an environmentally safe way. On the whole, the aim of bacterial cell disintegration is the release of cell contents in the form of an aqueous extract. Chemical disintegration of surplus activated sludge by alkalization results in destruction and disruption of the flocs and microorganisms as well as increase concentration of organic matter in supernatant. The mesophilic anaerobic sewage sludge digestion is an established process, most often applied at medium and large municipal sewage treatment plants. Four major steps of anaerobic digestion are distinguished. The first hydrolysis step leads to solubilization of insoluble particulate matter and biological decomposition of organic polymers to monomers or dimers. The hydrolysis step is recognized as the rate-limiting step of the following second and third steps, the processes of acidogenesis and acetogenesis. Chemical disintegration activates biological hydrolysis and, therefore, it can significantly increase the stabilization rate of the secondary sludge. It has been shown that when the activated sludge was subjected to alkalization to $\mathrm{pH} 9.0$ value, the COD concentration increased from 101 to $530 \mathrm{mg} / \mathrm{dm}^{3}$ in sludge supernatant. The paper presents a potential application of chemical disintegration for sewage sludge (mainly activated sludge) to upgrading biogas production.
\end{abstract}

Keywords: alkalization of waste activated sludge, $\mathrm{pH}$ value, methane fermentation, COD, proteins, alkaline conditioning

\section{Introduction}

Increasing sludge production poses a large problem to communities and local wastewater treatment plant operators. Sludge is a useful bioresource, and its anaerobic digestion is of high interest. Anaerobic sewage sludge digestion is an established, most often applied at medium and large municipal sewage treatment plants which used a relatively large hydraulic retention time (HRT) in the range of 20 to 30 days.

\footnotetext{
${ }^{1}$ Institute of Engineering and Environmental Protection, Faculty of Materials and Environmental Sciences, University of Bielsko-Biala, ul. Willowa 2, 43-309 Bielsko-Biała, phone +48 338279157

${ }^{2}$ Institute for Nanomaterials, Advanced Technology and Innovation, Technical University of Liberec, ul. Studentská 1402/2, 46117 Liberec 1, Czech Republic, phone +420 485353006

*Corresponding author: kgrubel@ath.bielsko.pl
} 
Conventionally, anaerobic digestion is carried out at mesophilic temperatures $\left(25-40^{\circ} \mathrm{C}\right)$. Four major steps of anaerobic digestion are distinguished. The first hydrolysis step leads to solubilization of insoluble particulate matter and biological decomposition of organic polymers to monomers or dimers. The hydrolysis step is recognized as the rate-limiting step of the following second and third steps, the processes of acidogenesis and acetogenesis. Especially anaerobic digestion of waste activated sludge (WAS) is often slow due to the rate limiting cell lysis step.

Several techniques are investigated to upgrade the effects of organics decomposition and dissolution by introduction pretreatment hydrolysis and to find more efficient pretreatment in order to enhance the methane yield (biogas production) from anaerobic digestion. There are several pretreatments of waste activated sludge (WAS) options: physical, mechanical, chemical or thermal nature external forces can be used for activated sludge floc's destruction. Some of them have already been introduced in full technical scale, among them hydrodynamic disintegration and ultrasound technologies. The goal of each of these pretreatments is to increase the liquid fraction in order to make the sludge biomass more biodegradable.

Chemical decomposition is effectuated through distinct $\mathrm{pH}$ lowering or raising. Acidification or alkalization, are probable the simplest processes for particulate organic matter hydrolysis. The effects of $\mathrm{pH}$ decrease or increase have been studied by many authors [1-3]. Chen et al [4] investigated the effect of $\mathrm{pH}$ from 4.0 to 11.0 on the WAS hydrolysis. They concluded that under alkaline conditions the volatile fatty acids (VFA) production was significantly higher than under other conditions. However, keeping $\mathrm{pH}$ on the level of 10.0 and 11.0, there was no methane generation.

In compare to other methods, alkaline pre-treatment have some advantages, ie simple devices, easy to operate and high efficiency [5].

Chemical sludge conditioning in combination with other disintegration technologies, like ultrasound or thermal treatment (low temperature between 50 and $70^{\circ} \mathrm{C}$ ) was earlier investigated. In the literature the increase of soluble chemical oxygen demand (SCOD) or decrease of volatile solids especially during alkaline treatment in combining with thermal treatment is stressed [6-8]. Another technology of chemical treatment with high pressure treatment - "Microsludge" [9] has also emerged.

Alkaline conditioning with sodium hydroxide (dose of $0.2 \mathrm{~g} / \mathrm{g}$ VS) also aided with ultrasonic field (ultrasonic pretreatment) was also investigated [3]. The effects of alkaline treatment and gamma ray irradiation on the hydrolysis of WAS, was studied by Kim et al [5], showing positive results. Combining sonication with alkalization and thermal pretreatment methods determined that this can significantly improve the sludge disintegration and decrease the required energy to reach the same yield by sonication [10].

Another chemical decomposition approach is based on application of strong oxidants, like chlorine, ozone or Fenton reagent [8, 11-14].

The aim of lab-scale investigation was combined effective process of WAS prehydrolysis. It was based on soft alkaline sludge conditioning as the pretreatment procedure. Alkaline sludge treatment leads to the partial dissolution or destruction of flocs structure, swelling, and subsequent solubilisation, of cell walls. A disruption of bacterial cells by the combination of alkaline treatment has a positive effect and upgrade the effectiveness of anaerobic sludge digestion in terms of biogas production and sludge quantity minimization. 


\section{Methods and material}

\section{Disintegration method}

Recirculated waste activated sludge (RWAS) samples, from the secondary settling tanks - concentration of suspended solids (SS) in average $9.51 \mathrm{~g} / \mathrm{dm}^{3}$, was taken from municipal wastewater treatment plant in the south of Poland, working according to the Enhanced Biological Nutrient Removal (EBNR) processes.

\section{Alkalization}

For chemical RWAS disintegration (destruction of activated sludge flocs and microorganisms cells) $2 \mathrm{M} \mathrm{NaOH}$ was used. In our study sodium hydroxide was added to samples of activated sludge in amounts sufficient to maintain a given $\mathrm{pH}$ value $(8,9,10$ and 11) for 30 minutes. Approximately from 0.8 to $6 \mathrm{~cm}^{3} \mathrm{NaOH}$ per $\mathrm{dm}^{3}$ of WAS.

\section{Analytical methods}

All chemical analyses were performed for samples before and after each phase of disintegration and during anaerobic digestion. All chemical and physical parameters were determined according to the procedures given in the Standard Methods for Examination of Water and Wastewater $\left(21^{\text {th }}\right.$ ed.). In the taken samples of activated sludge the SCOD (soluble chemical oxygen demand) value and content of suspended solids was analyzed [15], the protein concentration was determined by the Lowry method [16].

For colorimetric determinations, a spectrophotometer HACH DR4000 was applied. Chemical analyses were measured for samples before and after each time of disintegration. Centrifugation has been done in all cases for 10 min with 30,000 g.

$\mathrm{pH}$ and conductivity measurements were carried out with a WTW inoLab Level2 meter, equipped with a SenTix K1 electrode for $\mathrm{pH}$.

\section{Anaerobic digestion studies}

The anaerobic digestion experiments were performed in four glass fermenters (4.0 $\mathrm{dm}^{3}$ volume). The reactors have been located in thermostatic cabinets, with constant temperatures $35 \pm 1^{\circ} \mathrm{C}$, ie under mesophilic conditions with a holding time of 25 days.

Different rates of raw and disintegrated activated sludge have been applied:

Fermenter 1 - was fed $70 \%$ recirculated waste activated sludge (RWAS) $+30 \%$ digested sludge (DS, inoculum),

Fermenter 2 - was fed 50\% RWAS + 30\% DS + 20\% sludge after alkalization (RWASD),

Fermenter 3 - was fed $40 \%$ RWAS $+30 \%$ DS $+30 \%$ RWASD,

Fermenter 4 - was fed $30 \%$ RWAS $+30 \%$ DS + 40\% RWASD.

The volume of produced biogas was determined by liquid displacement method ever each day. Biogas composition $\left(\mathrm{CH}_{4}, \mathrm{CO}_{2}\right.$ and $\left.\mathrm{O}_{2}\right)$ was analysed every day of digestion with gas analyser Gas Data GFM 416.

\section{Results and discussion}

According to the described earlier methodology $\mathrm{NaOH}$ was added in amounts sufficient to maintain a given $\mathrm{pH}$ value for 30 minutes. The volume of $\mathrm{NaOH}$ added per $1 \mathrm{dm}^{3}$ increase with $\mathrm{pH}$ value and it was shown in Figure 1. 


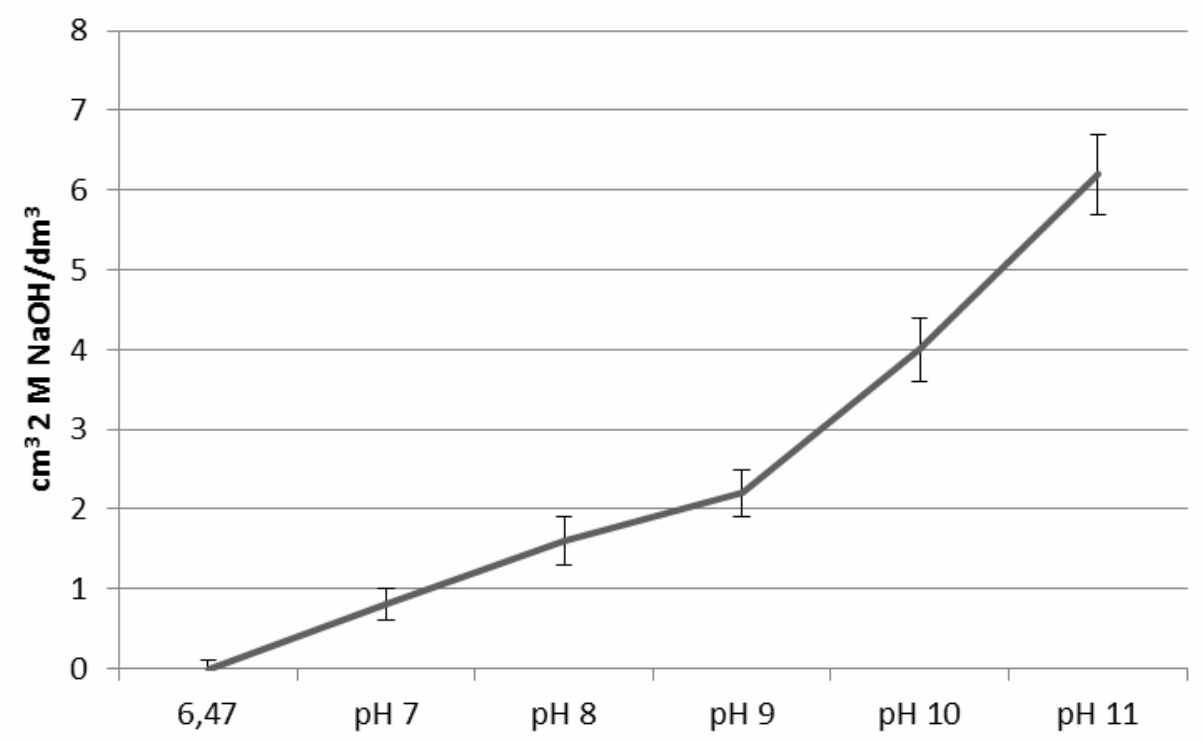

Fig. 1. The volume of $2 \mathrm{M} \mathrm{NaOH}$ added per $1 \mathrm{dm}^{3}$ of activated sludge to achieve $\mathrm{pH}$ value

Destruction of activated sludge flocks results in the first phase of attached film release and bio-polymeric substances, followed by lyses of bacterial cells and release of internal substances.

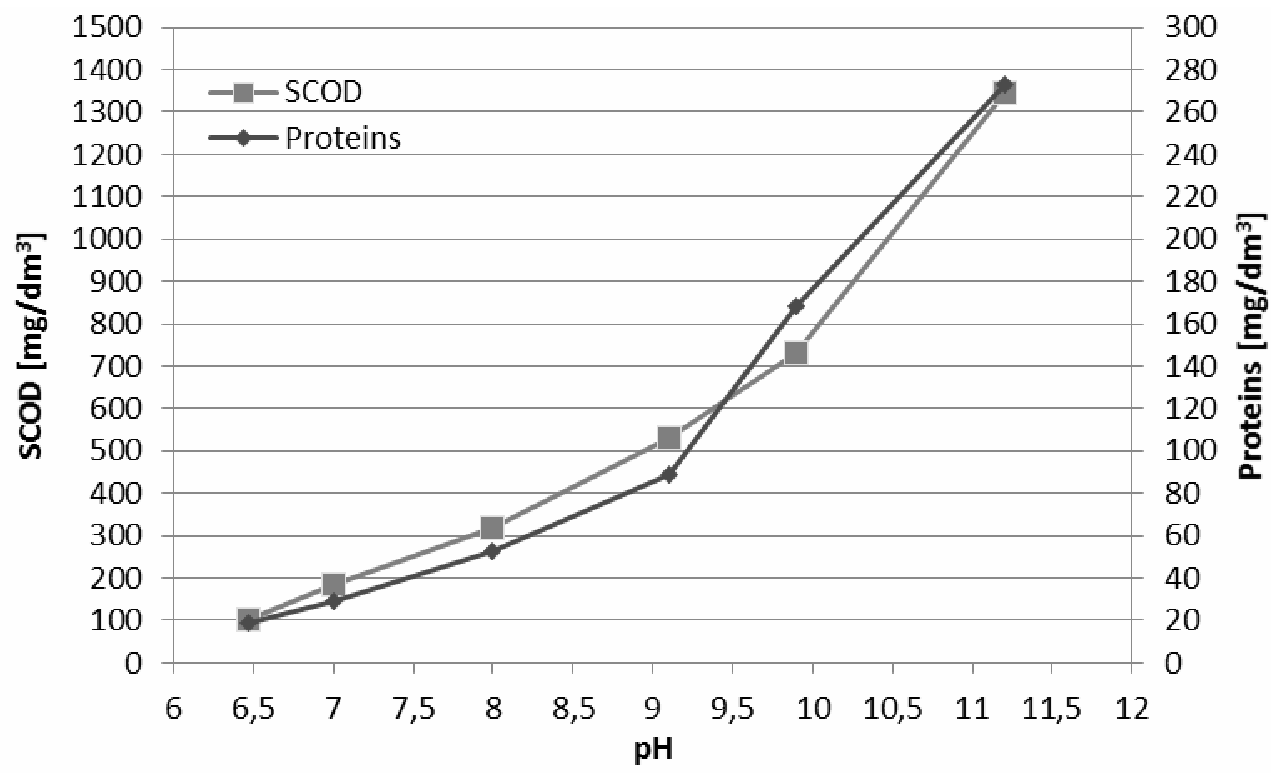

Fig. 2. Release of SCOD and proteins during alkalization process 
According to the described earlier methodology $\mathrm{NaOH}$ was added in amounts sufficient to maintain a given $\mathrm{pH}$ value for 30 minutes. The effects of bacteria cells lyses and accompanied organic substances release after that time was measured as soluble chemical oxygen demand in supernatant - SCOD, and/or proteins concentration. In agreements with the expectations, an increase of the $\mathrm{pH}$ value resulted in higher values of measured SCOD and proteins concentrations (Fig. 2).

Şahinkaya et al [17] investigated under similar conditions the effects of disintegrations using $\mathrm{NaOH}$ and they achieved sludge disintegration - 24.4\%. Similar results using this method had Zhang et al [18]. Kim et al [2] conducted alkaline pre-treatment at pH 12 with several alkaline agents: $\mathrm{NaOH}, \mathrm{KOH}, \mathrm{Mg}(\mathrm{OH})_{2}$ and $\mathrm{Ca}(\mathrm{OH})_{2}$. At ambient temperature, the COD solubilization values after $\mathrm{NaOH}, \mathrm{KOH}, \mathrm{Mg}(\mathrm{OH})_{2}$ and $\mathrm{Ca}(\mathrm{OH})_{2}$ addition were 39.8, 36.6, 10.8 and $15.3 \%$, respectively. Similarly, following treatment at $121^{\circ} \mathrm{C}$ for $30 \mathrm{~min}$, $\mathrm{NaOH}$ addition resulted in $51.8 \%$ COD solubilization with the other values being 47.8, 18.3 and 17.1 , respectively [2].

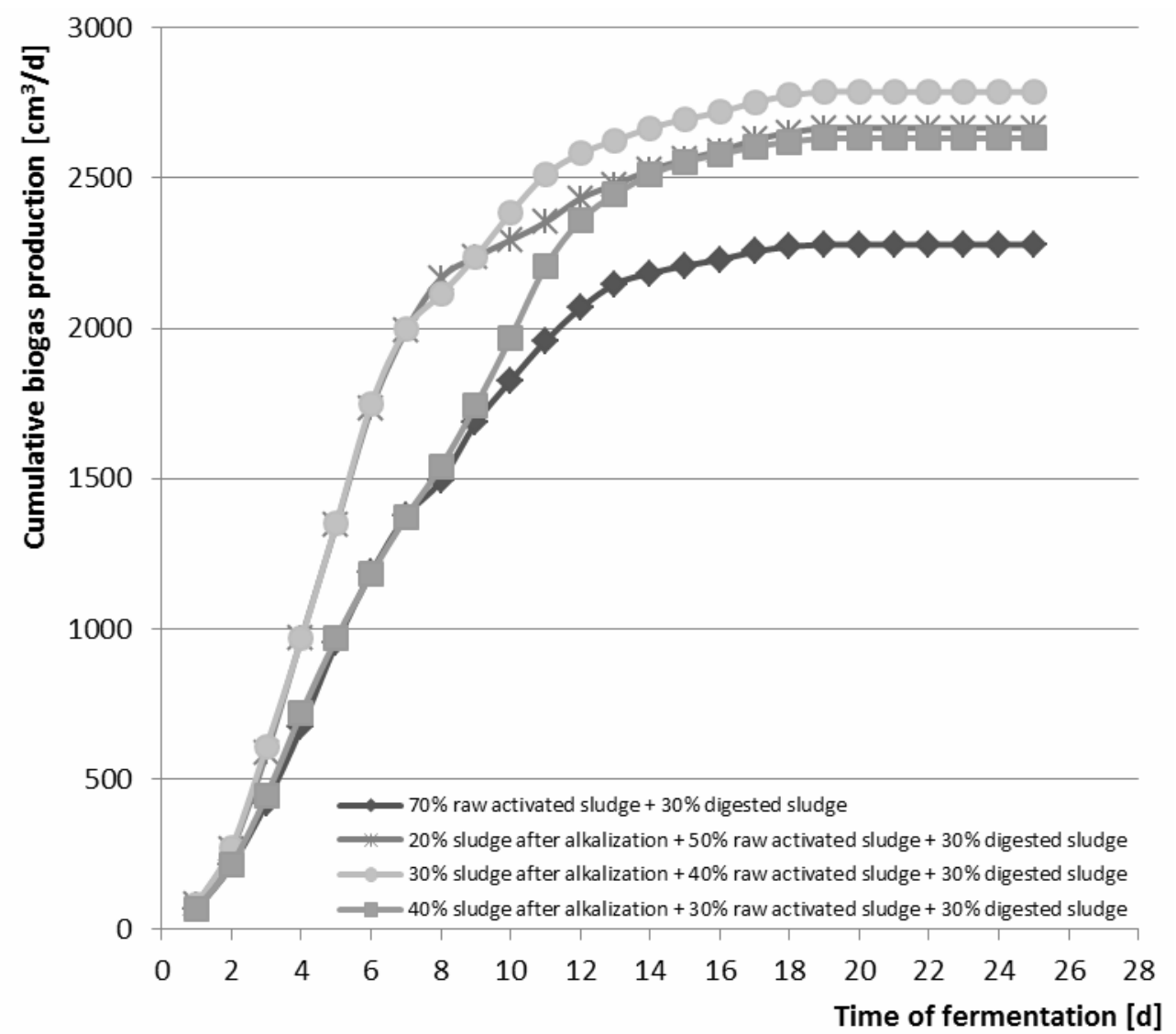

Fig. 3. Cumulative biogas production in the mesophilic conditions for four different composition of the supplied sludge 
Chemical disintegration accelerates the biological degradation of sludge. The cell liquid contains components, which upon being released, can be easily assimilated. The released organic substances (expressed here as SCOD) as a result of activated sludge floc's disintegration, lead to a substantial increase of biogas production in the subsequent anaerobic sludge digestion process (Fig. 3).

According to the methodology, the determination of the effectiveness of mesophilic anaerobic digestion aiming at enhancement of biogas production and solids degradation was carried out. Carried out experiment have confirmed the aforementioned observation, that chemical disintegration of only a part of RWAS is substantiated. The portion of disintegrated sludge investigated was 20, 30 and $40 \%$ in the mixture of inocula and not treated RWAS. The obtained effects, measured as biogas production for a part of activated sludge chemically disintegrated is presented in Figure 3.

The mesophilic anaerobic digestion stage $(35 \pm 1)^{\circ} \mathrm{C}$, amounted to 25 days. The obtained results are demonstrating the distinct effect of gas (biogas) production increase, caused by partial sludge disintegration. For the cases; non disintegrated activated sludge and the mixture containing of $30 \%$ disintegrated sludge, much higher production of biogas in the mesophilic anaerobic digestion was observed. About $2280 \mathrm{~cm}^{3} / \mathrm{d}$ and $2790 \mathrm{~cm}^{3} / \mathrm{d}$ for no disintegrated sludge and sample with RWASD was achieved, respectively.

Significantly higher amounts of biogas were produced in the fermenters fed with disintegrated activated sludge (20,30 or $40 \%$ volume of fermenter). In experiment done by Li et al [6] at the initial stage of fermentation, biogas production of all the samples was similar till the fifth day. At first, the soluble or easily dissolved organic substances were consumed. The substrate was sufficient for the anaerobic bacteria even without alkalization. The gas production during sludge digestion depends on volatile solids, degree of disintegration (expressed as SCOD) and fermentation time. Volatile solids of activated sludge content ranges from 62 to over $64 \%$.

Table 1

Biogas composition of four feed varieties

\begin{tabular}{|c|c|c|}
\hline Feed varieties & Biogas composition & $\begin{array}{c}\text { Mesophilic } \\
\text { conditions }\left(35 \pm 1^{\circ} \mathrm{C}\right)\end{array}$ \\
\hline \multirow{3}{*}{$70 \%$ RWAS + $30 \%$ DS } & $\mathrm{CH}_{4}[\%]$ & $58-60$ \\
\hline & $\mathrm{CO}_{2}[\%]$ & $30-34$ \\
\hline & $\mathrm{O}_{2}[\%]$ & $0.2-0.4$ \\
\hline \multirow{3}{*}{$50 \%$ RWAS + $30 \%$ DS + $20 \%$ RWASD $(\mathrm{NaOH})$} & $\mathrm{CH}_{4}[\%]$ & $59-64$ \\
\hline & $\mathrm{CO}_{2}[\%]$ & $30-35$ \\
\hline & $\mathrm{O}_{2}[\%]$ & $0.3-0.5$ \\
\hline \multirow{3}{*}{$40 \%$ RWAS + 30\% DS + 30\% RWASD $(\mathrm{NaOH})$} & $\mathrm{CH}_{4}[\%]$ & $60-64$ \\
\hline & $\mathrm{CO}_{2}[\%]$ & $32-35$ \\
\hline & $\mathrm{O}_{2}[\%]$ & $0.3-0.4$ \\
\hline \multirow{3}{*}{$30 \%$ RWAS + 30\% DS + 40\% RWASD $(\mathrm{NaOH})$} & $\mathrm{CH}_{4}[\%]$ & $62-66$ \\
\hline & $\mathrm{CO}_{2}[\%]$ & $33-36$ \\
\hline & $\mathrm{O}_{2}[\%]$ & $0.2-0.4$ \\
\hline
\end{tabular}

Table 1 shows the average biogas composition (methane, carbon dioxide and oxygen) at the mesophilic temperature range. The average $\mathrm{CH}_{4}$ content ranged from 58 to $66 \%$, average content of $\mathrm{CO}_{2}$ ranged from 30 to $36 \%$ for mesophilic conditions. Oxygen content in the biogas was under $1 \%$. That means that the digestion was anaerobic. 
Figure 4 shows the changes of total and volatile solids during two stage digestion process (at the mesophilic temperature range). After anaerobic digestion, the total solids concentration has decreased by about $31 \%$ for the raw sample (70\% RWAS $+30 \%$ DS) and about $33 \%$ for sample with a part ( $40 \%$ of volume) of chemically disintegrated sludge. The highest volatile solids reduction at mesophilic temperature range was achieved for addition of $30 \%$ by volume (RWASD), ie about $44 \%$. It was about $5 \%$ greater than the reduction of volatile solids in the reference sample (70\% RWAS + 30\% DS).

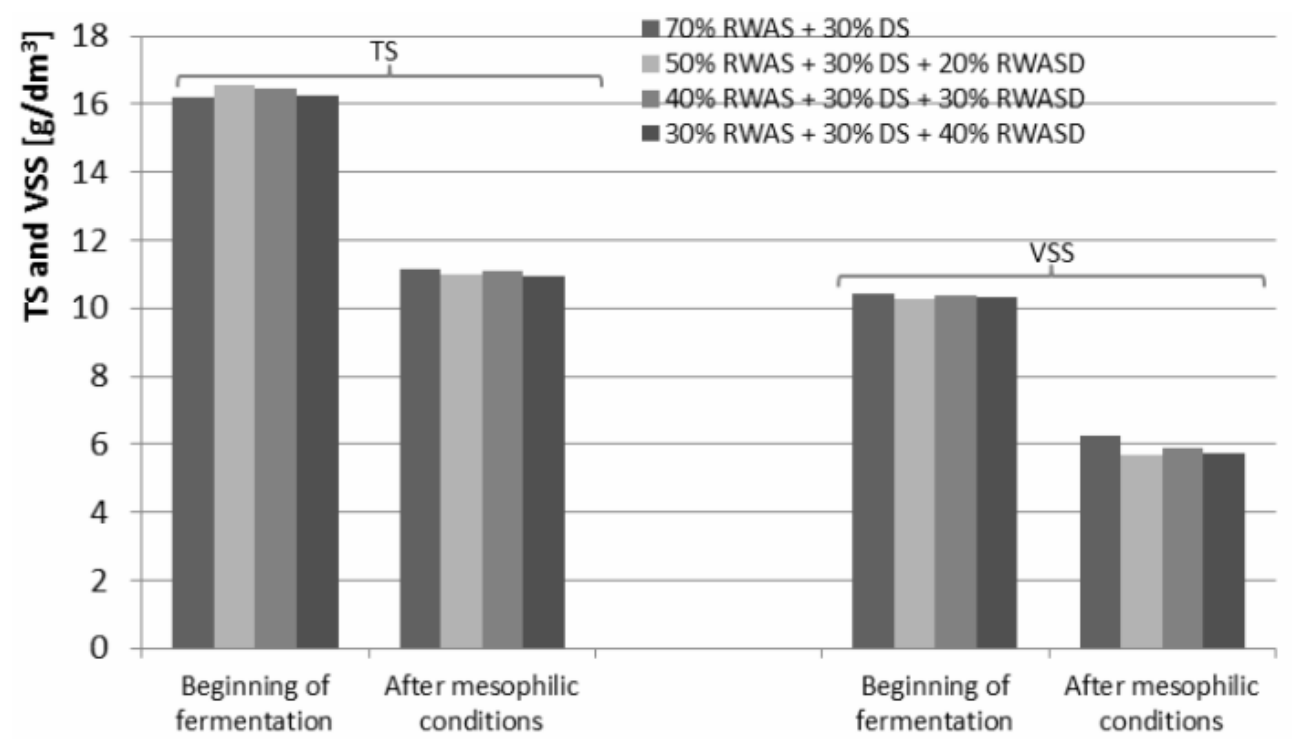

Fig. 4. Decrease of total and volatile solids after mesophilic conditions for four different composition of the supplied sludge

The organic matter transferred by chemical treatment from the sludge solids into the liquid phase was readily biodegradable. Activated sludge consists mainly of heterotrophic bacteria. The gradual break-up of the bacterial cell walls limits the degradation process. By applying $\mathrm{NaOH}$ the destruction of cells occurs in minutes instead of days. The intracellular and extracellular components are set free and are immediately available for biological degradation which leads to an improvement of the subsequent anaerobic process. In Figure 3 , this is shown by comparing the increase of biogas production in the anaerobic digestion, post chemical disintegration. Li et al [3] observed that pretreatment with a low dosage of $\mathrm{NaOH}$ did not dissolve the organic matter much. However pretreatment with huge dosage, reduced activity of the anaerobic sludge. Therefore, $\mathrm{pH}$ start of the anaerobic digesters should be monitored at a $\mathrm{pH}$ lower than 8.0 after the alkali-treated sludge is fed into the digesters. Mostly, alkalization is used witch some other disintegration methods (sonification [10, 17], thermal pretreatment [10], high pressure homogenization [18]) to increase the efficiency of whole process but usually this is financially unfavorable cause of a high energy expending process. 


\section{Conclusions}

Chemical disintegration is a suitable method to destroy the microorganisms of activated sludge. In this study, alkalization was examined, with the aim of releasing organic matter and upgrading biogas production.

Rapid and high effects of organic matter resolution can be obtained in the process of alkalization up to $\mathrm{pH} 9.0$.

The increased $\mathrm{pH}$ of the sludge feed, mixed with the sludge present in the digester immediately lowered to values prevailing in methanogenic processes. There is no toxic effect to the microorganisms, neither corrosiveness.

The experiments have clearly demonstrated that the soft alkaline sludge conditioning, $\mathrm{pH}$ 9.0, as a pretreatment procedure is a suitable method to destroy activated sludge flocs and microorganisms and advance hydrolysis which is the rate-limiting step of anaerobic digestion.

The most important conclusions of this study are:

1. Chemical disintegration causes the transfer of organic matter from the sludge solids into the liquid phase (expressed as SCOD). It has been shown that when the activated sludge was subjected to alkalization to $\mathrm{pH} 9.0$ value, the SCOD concentration increased from 101 to $530 \mathrm{mg} / \mathrm{dm}^{3}$ in sludge supernatant.

2. Disintegration of activated sludge by alkalization permits achievement of intensification of biogas production. After 25 days of the anaerobic process, the biogas production increased by about $22 \%$. The chemical disintegration of activated sludge leads to a higher degree of degradation and higher biogas production. Addition of disintegrated sludge $(20,30$ and $40 \%$ of volume) to the anaerobic digestion caused increase biogas production about 15, 22 and $16 \%$ in comparison with the undisintegrated activated sludge, respectively.

3. The highest volatile solids reduction at mesophilic temperature range was achieved for addition of $30 \%$ by volume (RWASD), ie about $44 \%$. It was about $5 \%$ greater than the reduction of volatile solids in the reference sample (70\% RWAS + 30\% DS).

\section{Acknowledgements}

This work was supported by the EU ROUTES project (Contract No 265156, FP7 2007-2013, THEME [ENV.2010.3.1.1-2] Innovative system solutions for municipal sludge treatment and management).

\section{References}

[1] Lin JG, Chang CN, Chang SC. Bioresour Technol. 1997;62:85-90. DOI: 10.1016/S0960-8524(97)00121-1.

[2] Kim J, Park C, Kim T-H. J Biosci and Bioeng. 2003;95(3):271-275. DOI: 10.1016/S1389-1723(03) 80028-2.

[3] Li H, Jin Y, Mahar RB, Wang Z, Nie Y. Bioresour Technol. 2008;99:5140-5144. DOI: 10.1016/j.biortech.2007.09.019.

[4] Chen Y, Jiang S, Hongying Y, Zhou Q, Gu G. Water Res. 2007;41:683-689. DOI: 10.1016/j.watres.2006.07.030.

[5] Kim T-Hun, Kim T-Hyun, Yu S, Nam YK, Choi D-K, Lee SR, Lee M-J. Bioresour Technol. 2007;13(7):1149-1153. DOI: 10.1016/j.biortech.2009.06.049.

[6] Li H, Li C, Liu W, Zou S. Bioresour Technol. 2012;123:189-194. DOI: 10.1016/j.biortech.2012.08.017.

[7] Neyens E, Bbaeyens J, Dwil R, de Heyder B. J Hazard Mater. 2004;106B:83-92. 
[8] Vlyssides AG, Karlis PK. Bioresour Technol. 2004;91:201-206. DOI: 10.1016/S0960-8524(03)00176-7.

[9] Rabinowitz B, Stephenson R. Proc of the 78th Ann Conf of the Water Environ Federat. 2005;12. DOI: $10.2175 / 193864706783711018$.

[10] Sahinkaya S, Sevimli MF, Aygun A. Water Sci \& Technol. 2012;65:1809-1816. DOI: 10.2166/wst.2012.074.

[11] Deleris S, Rouston JM. Ozone: Sci \& Eng: The Journal of the Internatl Ozone Associat. 2000;22:473-486. DOI: $10.1080 / 01919510009408791$.

[12] Kitis M, Adams CD, Daigerg T. Water Res. 1999;33:2561-2568. DOI: 10.1016/S0043-1354(98)00476-X.

[13] Erden G, Filibeli A. Desalination, 2010;251:58-63. DOI: 10.1016/j.desal.2009.09.144,251,58-63.

[14] Roberts R, Son L, Foster CF. J Chem Technol Biotechnol. 1999;74:445-450. DOI: 10.1002/(SICI)1097-4660(199905)74:5<445.

[15] Eaton AD, Clesceri LS, Greenberg AE, editors. Standard Methods for the Examination of Water and Wastewater (19th edn.) Washington: American Public Health Association; 1995.

[16] Gerhardt P, Murray RGE, Wood WA, Krieg NR. Methods for General and Molecular Bacteriology. Wahington DC: ASM; 2005.

[17] Şahinkaya S, Sevimli MF. J of Ind and Eng Chem. 2013;19:197-206. DOI: 10.1016/j.jiec.2012.08.002.

[18] Zhang Y, Zhang P, Zhang G, Ma W, Wu H, Ma B. Bioresour Technol. 2012;123:514-519. DOI: 10.1016/j.biortech.2012.07.078.

\title{
WPLYW ALKALIZACJI OSADU CZYNNEGO NADMIERNEGO NA PRODUKCJE BIOGAZU
}

${ }^{1}$ Zakład Mikrobiologii Środowiskowej, Instytut Ochrony i Inżynierii Środowiska Wydział Nauk o Materiałach i Środowisku, Akademia Techniczno-Humanistyczna

\begin{abstract}
Abstrakt: Osady, powstające w procesie oczyszczania ścieków, poddaje się procesom przeróbki i unieszkodliwiania w celu zmniejszenia ich objętości oraz pozbawienia ich szkodliwego wpływu na środowisko. Fermentacja metanowa jest jedną z najczęściej stosowanych metod biodegradacji materii organicznej zawartej w osadach ściekowych. W ostatnich latach odnotować można duże zainteresowanie badaczy działaniami wspomagającymi proces stabilizacji beztlenowej. Największe zainteresowanie dotyczy intensyfikacji procesu produkcji biogazu na drodze dezintegracji głównie mechanicznej, np. z wykorzystaniem ultradźwięków, homogenizacji nożowej czy też dezintegracji hydrodynamicznej. Oprócz fizycznych metod dezintegracji istnieje możliwość wykorzystania do tego celu procesów chemicznych - zakwaszania lub alkalizacji. W pracy starano się wykazać i określić wpływ jednej z metod dezintegracji - alkalizacji - osadu czynnego na proces stabilizacji beztlenowej. Dodatek substancji alkalizującej, np. wodorotlenku sodu, do osadu czynnego powoduje destrukcję kłaczków osadu oraz zmiękczanie ścian komórkowych mikroorganizmów budujących osad czynny, co w konsekwencji prowadzi do ich lizy. Uwalniana w ten sposób materia organiczna stanowi szybko i łatwo rozkładalny produkt, który w znacznym stopniu przyspiesza pierwszą fazę procesu stabilizacji beztlenowej, tj. fazę hydrolityczną. Konsekwencją tego jest przyspieszenie i wydłużenia fazy metanogennej, dzięki czemu zwiększa się ilość wyprodukowanego biogazu. Na podstawie uzyskanych wyników można wnioskować, że dezintegracja alkaliczna bardzo dobrze nadaje się do wstępnego kondycjonowania osadów. Znacznie zwiększona ilość wyprodukowanego biogazu, jak również niska cena $\mathrm{NaOH}$ zachęca do korzystania $\mathrm{z}$ tego procesu jako wstępnego przygotowania osadów przed ich stabilizacją.
\end{abstract}

Słowa kluczowe: osady ściekowe, fermentacja, alkalizacja, biogaz 